\title{
A Concise Review of Chromatographic Methods for the Analysis of Benzene and its Metabolites
}

\author{
Haseeb Ahmad Khan \\ Department of Biochemistry, College of Science, King Saud University, P. O. Box 2455, Riyadh, Saudi Arabia \\ (E-mail: haseeb@ksu.edu.sa)
}

RECEIVED SEPTEMBER 2, 2004; REVISED FEBRUARY 24, 2005; ACCEPTED MARCH 29, 2005

\section{INTRODUCTION}

Benzene is an important contaminant with carcinogenic effects. ${ }^{1}$ The potential sources of benzene exposure include its industrial usage, gasoline vapors, engine exhaust and tobacco smoke. Such a massive environmental or occupational exposure of benzene poses serious health hazard to worldwide population. The biological control of exposition to benzene is of great importance to prevent its toxic and carcinogenic effects and it is therefore very relevant to monitor environmental quality as well as benzene exposure in individuals. Although part of benzene is excreted intact from the body, a major portion of benzene is converted into several metabolites including $S$-phenyl mercapturic acid (S-PMA), trans, trans-muconic acid ( $t, t$-MA), phenol, catechol and hydroquinone (Figure 1). The relative production of benzene metabolites is directly proportional to its exposure level. ${ }^{2} \mathrm{Qu}$ et $a l .{ }^{3}$ have discussed the applicability of these metabolites as possible biomarkers of benzene exposure in human population. $S$-PMA and $t, t$-MA have been recognized as the most sensitive markers of low-level benzene expo- sure. On the other hand, urinary excretion of un-metabolized benzene has also been used for the evaluation of its low-level environmental exposure. ${ }^{4}$ Numerous methods have been developed to analyze benzene and its metabolites to evaluate benzene exposure so that effective preemptive measures could be timely imposed. The aim of this short-review is to summarize various chromatographic methods for the estimation of benzene and its metabolites in different environmental and biological samples.

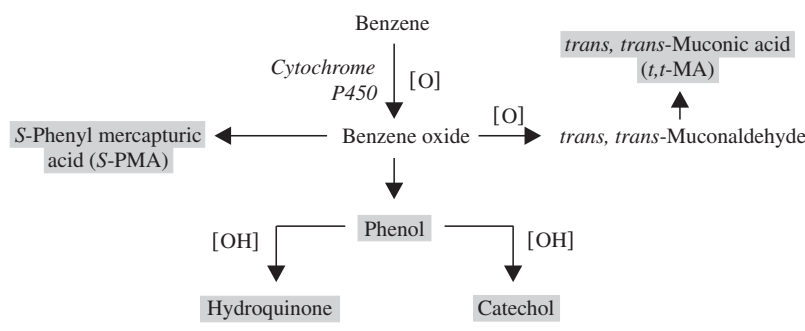

Figure 1. Schematic presentation of metabolic pathways of benzene degradation. Shaded metabolites are important biomarkers of benzene exposure. 


\section{ANALYSIS OF BENZENE}

\section{Air/breath}

A simple and reliable field method for the analysis of benzene in exhaled air has been reported by Ljungkiust and Norlinder. ${ }^{5}$ The sample was collected directly on absorbent tube using modified sampling device and desorbed thermally for the analysis by gas chromatography (GC). The advantages of this method were suggested to be easy transportation, stability of samples (1 week), no sample preparation or clean up and low detection limit $\left(0.5 \mu \mathrm{g} / \mathrm{m}^{3}\right) .{ }^{5}$ Recently, Yamada et al. ${ }^{6}$ have used passive air samplers packed with activated charcoal to absorb volatile organic compounds including benzene prior to analysis by GC coupled with flame ionization detection (GC-FID), with determination limit of $0.3 \mu \mathrm{g} / \mathrm{m}^{3}$. A battery operated gas chromatography-mass spectrometry $(\mathrm{GC}-\mathrm{MS})^{7}$ system has been devised for on-time monitoring of benzene concentrations in air while driving or refueling the vehicle, with a detection limit of $1 \mu \mathrm{g} / \mathrm{m}^{3}$. Saba et al. ${ }^{8}$ collected benzene from air samples using adsorbent cartridges with simultaneous adsorption of pre-established amounts of D6-labelled internal standard. Desorption of benzene was performed by solid-phase microextraction (SPME) prior to analysis by GC-MS with demonstrated linearity in the range of 10-400 ng of benzene. $^{8}$ Amagai and coworkers ${ }^{9}$ used GC-MS for determining benzene levels in indoor and outdoor air during summer (indoor, 0.694-3.11 $\mu \mathrm{g} / \mathrm{m}^{3}$; outdoor, 0.779-3.17 $\mu \mathrm{g} / \mathrm{m}^{3}$ ) and winter (indoor, $1.65-6.89 \mu \mathrm{g} / \mathrm{m}^{3}$; outdoor, $1.35-6.04 \mu \mathrm{g} / \mathrm{m}^{3}$ ). Wester et al. ${ }^{10}$ determined benzene in smokers' $(6.8 \pm 3.0 \mathrm{ppb})$ and nonsmokers' breath $(2.5 \pm$ $0.8 \mathrm{ppb})$ and smokers' ambient air $(3.3 \pm 0.8 \mathrm{ppb})$ using GC-MS. Gruenke and coworkers ${ }^{11}$ developed a sensitive headspace gas chromatography (HS-GC) method coupled with MS for the determination of benzene in air or breath with the detection limits of $0.1 \mathrm{ppb} / 5 \mathrm{dm}^{3}$ sample. The same method can also be applied for the analysis of benzene in blood samples with detection limit of $2 \mathrm{ng} / \mathrm{cm}^{3} .{ }^{11}$ Elke et al. ${ }^{12}$ reported an improved analytical method for determination of benzene, toluene, ethyl benzene and xylene (BTEX) in indoor air. The procedure consists of passive air sampling using commercially available diffusive samplers (charcoal pad), headspace SPME and high resolution GC-FID. The lower detection limit using $2 \mathrm{~h}$ sampling interval was in the range of $0.4-2 \mu \mathrm{g} / \mathrm{m}^{3}$. Tumbiolo et al. ${ }^{13}$ used a 30 min SPME sampling to detect BTEX in ambient air as well as standard gas mixture. The detection limit of this GC-MS procedure varied between 0.05 and $0.1 \mu \mathrm{g} / \mathrm{m}^{3}$ depending on the fiber used for SPME.

\section{Blood/urine}

Estimation of un-metabolized benzene in blood or urine is a useful index for the evaluation of benzene exposure in humans. Although analysis of benzene in breath samples can be reliably carried out by GC-MS, the use of HS-GC is more suitable for the determination of non-metabolized benzene in complex matrices like blood and urine. ${ }^{14}$ Pekari et al. ${ }^{15}$ determined benzene in blood using HS-GC equipped with a photoionization detector with the detection limit of $5 \mathrm{nmol} / \mathrm{dm}^{3}$, being sensitive

TABLE I. Chromatographic methods for the analysis of benzene in various matrices

\begin{tabular}{|c|c|c|c|c|c|}
\hline Sample & Detection limit & Method & Sample & Detection limit & Method \\
\hline \multirow[t]{9}{*}{ Air } & $0.5 \mu \mathrm{g} / \mathrm{m}^{3}$ & $\mathrm{GC}^{5}$ & Urine & $0.51 \mathrm{nmol} / \mathrm{dm}^{3}$ & HS-GC ${ }^{17}$ \\
\hline & $0.3 \mu \mathrm{g} / \mathrm{m}^{3}$ & $\mathrm{GC}^{6}$ & & $50 \mathrm{ng} / \mathrm{dm}^{3}$ & $\mathrm{GC}^{20}$ \\
\hline & $1 \mu \mathrm{g} / \mathrm{m}^{3}$ & $\mathrm{GC}^{-\mathrm{MS}^{7}}$ & & $6.5 \mathrm{ng} / \mathrm{dm}^{3}$ & HS-GC-MS ${ }^{21}$ \\
\hline & $10 \mathrm{ng}$ & GC-MS ${ }^{8}$ & & $12 \mathrm{ng} / \mathrm{dm}^{3}$ & HS-GC-MS 22 \\
\hline & $0.694 \mu \mathrm{g} / \mathrm{m}^{3}$ & GC-MS $^{9}$ & & $42 \mathrm{ng} / \mathrm{dm}^{3}$ & HS-GC 23 \\
\hline & $0.1 \mathrm{ppb}$ & HS-GC-MS ${ }^{11}$ & & $7 \mathrm{ng} / \mathrm{dm}^{3}$ & HS-GC ${ }^{24}$ \\
\hline & $0.4 \mu \mathrm{g} / \mathrm{m}^{3}$ & HS-GC ${ }^{12}$ & & $12 \mathrm{ng} / \mathrm{dm}^{3}$ & HS-GC-MS ${ }^{25}$ \\
\hline & $0.05 \mu \mathrm{g} / \mathrm{m}^{3}$ & HS-GC-MS ${ }^{13}$ & & $0.31 \mathrm{ppb}$ & HS-GC-MS ${ }^{26}$ \\
\hline & & & & $0.043 \mathrm{ng} / \mathrm{cm}^{3}$ & HS-GC-MS 27 \\
\hline \multirow[t]{2}{*}{ Breath } & $2.5 \mathrm{ppb}$ & GC-MS ${ }^{10}$ & & $0.28 \mathrm{ppb}$ & HS-GC-MS ${ }^{28}$ \\
\hline & $0.1 \mathrm{ppb}$ & HS-GC-MS ${ }^{11}$ & & $0.016 \mu \mathrm{g} / \mathrm{dm}^{3}$ & HS-GC-MS 29 \\
\hline \multirow[t]{6}{*}{ Blood } & $2 \mathrm{ng} / \mathrm{cm}^{3}$ & HS-GC-MS ${ }^{11}$ & Water & $0.1 \mu \mathrm{g} / \mathrm{dm}^{3}$ & $\mathrm{GC}^{30}$ \\
\hline & $5 \mathrm{nmol} / \mathrm{dm}^{3}$ & HS-GC ${ }^{15}$ & & $15 \mathrm{ng} / \mathrm{dm}^{3}$ & $\mathrm{GC}^{35}$ \\
\hline & $1 \mu \mathrm{g} / \mathrm{cm}^{3}$ & HS-GC 16 & & $0.07 \mu \mathrm{g} / \mathrm{dm}^{3}$ & HS-GC 36 \\
\hline & $0.64 \mathrm{nmol} / \mathrm{dm}^{3}$ & HS-GC 17 & & & \\
\hline & $1.1 \mathrm{ng} / 0.5 \mathrm{~cm}^{3}$ & HS-GC ${ }^{18}$ & Soil & $0.8 \mu \mathrm{g} / \mathrm{dm}^{3}$ & $\mathrm{GC}^{44}$ \\
\hline & $16 \mathrm{ng} / \mathrm{dm}^{3}$ & HS-GC-MS ${ }^{19}$ & & $0.2 \mathrm{ng}$ & HS-GC ${ }^{45}$ \\
\hline
\end{tabular}


enough for biological monitoring of benzene in exposed workers. Alegretti et al. ${ }^{16}$ used SPME and HS-GC connected to FID detector for simultaneous determination of benzene, toluene and xylene in human blood samples. The detection limit for benzene was found to be $1 \mu \mathrm{g} / \mathrm{cm}^{3}$. Kok and Ong ${ }^{17}$ described a sensitive HS-GC method for the determination of benzene in blood and urine samples using silicone gum capillary column and photoionization detector. The recovery was more than $90 \%$ and the detection limits for blood and urinary benzene were 0.64 and $0.51 \mathrm{nmol} / \mathrm{dm}^{3}$ respectively. ${ }^{17}$ Lee and coworkers ${ }^{18}$ used headspace SPME for extraction of five thinner components including benzene, toluene, butyl acetate, 1-butanol and isoamyl acetate from whole blood and urine samples. A polydimethylsiloxane-coated SPME fiber was exposed to the headspace of preheated $\left(80{ }^{\circ} \mathrm{C}\right)$ sample vial to allow the absorption of the compounds. The fiber needle was then injected into a capillary GC for quantitation. The recovery was 50-70 \% and the detection limit ranged $1.1-2.4 \mathrm{ng} / 0.5 \mathrm{~cm}^{3}$ sample. ${ }^{18}$ Perbellini et al. ${ }^{19}$ determined BTEX in blood and urine samples using HS-GC coupled with MS detector; the limit of detection was $16 \mathrm{ng} / \mathrm{dm}^{3}$.

Fiorentino and coworkers ${ }^{20}$ developed a method to evaluate low concentrations of benzene in urine samples by means of a dynamic headspace $\left(50 \mathrm{~cm}^{3}\right.$ of urine in a $120 \mathrm{~cm}^{3}$ vial). The urine was saturated with anhydrous $\mathrm{Na}_{2} \mathrm{SO}_{4}$ in order to support the entrance of benzene in the air over urine. The solvent was stripped from the urine surface and concentrated on an adsorbent substrate by means of a suction pump. Benzene was thermally desorbed and injected into a GC column. The detection limit of the method was $50 \mathrm{ng} / \mathrm{dm}^{3}$ with coefficient of variation to be $4.7 \%$. Ljungkvist et al. ${ }^{21}$ determined benzene in urine using a procedure based on dynamic head-space, analyte preconcentration on a solid sorbent, thermal desorption and subsequent analysis by GC-MS. The lower limit of detection was $6.5 \mathrm{ng} / \mathrm{dm}^{3}$ and the stability of

TABLE II. Chromatographic methods for the analysis of S-PMA and $t, t-M A$ in urine samples

\begin{tabular}{|c|c|c|}
\hline Metabolite & Detection limit & Method \\
\hline \multirow[t]{5}{*}{$S$-PMA } & $60 \mathrm{ng} / \mathrm{dm}^{3}$ & $\mathrm{GC}^{53}$ \\
\hline & $2 \mu \mathrm{g} / \mathrm{dm}^{3}$ & GC-MS ${ }^{54}$ \\
\hline & $3 \mathrm{mg} / \mathrm{dm}^{3}$ & HPLC $^{56}$ \\
\hline & $0.3 \mu \mathrm{g} / \mathrm{dm}^{3}$ & $\mathrm{LC} / \mathrm{MS} / \mathrm{MS}^{64}$ \\
\hline & $<30 \mathrm{ng} / \mathrm{cm}^{3}$ & $\mathrm{LC} / \mathrm{MS} / \mathrm{MS}^{65}$ \\
\hline \multirow[t]{6}{*}{$t, t$-MA } & $10 \mu \mathrm{g} / \mathrm{dm}^{3}$ & GC-MS ${ }^{54}$ \\
\hline & $25 \mu \mathrm{g} / \mathrm{dm}^{3}$ & $\mathrm{EC}^{55}$ \\
\hline & $3 \mu \mathrm{g} / \mathrm{dm}^{3}$ & HPLC $^{60}$ \\
\hline & $0.05 \mathrm{mg} / \mathrm{dm}^{3}$ & HPLC $^{62}$ \\
\hline & $6 \mu \mathrm{g} / \mathrm{dm}^{3}$ & $\mathrm{LC} / \mathrm{MS} / \mathrm{MS}^{64}$ \\
\hline & $3 \mathrm{ng} / \mathrm{cm}^{3}$ & $\mathrm{LC} / \mathrm{MS} / \mathrm{MS}^{65}$ \\
\hline
\end{tabular}

frozen samples was at least one month. Fustinoni et al. ${ }^{22}$ used SPME for sampling BTEX from the headspace of urine followed by their selective analysis by GC-MS with detection limits of $12-34 \mathrm{ng} / \mathrm{dm}^{3}$. They also observed that BTEX remained stable for 2 months in frozen urine samples. Skender and coworkers ${ }^{23}$ compared benzene levels in the urine of smokers and nonsmokers using $\mathrm{HS}-\mathrm{GC}$ with the quantitation limit of $42 \mathrm{ng} / \mathrm{dm}^{3}$. Ljungkvist et al. ${ }^{24}$ determined benzene in urine of occupationally or environmentally exposed persons using HS-GC based on dynamic headspace, solid phase preconcentration, thermal desorption and flame ionization detection. The limits of detection and quantitation were $7 \mathrm{ng} / \mathrm{dm}^{3}$ and $23 \mathrm{ng} / \mathrm{dm}^{3}$ respectively. The frozen samples were stable for 1 year as compared to 1 week stability of refrigerated samples $\left(4{ }^{\circ} \mathrm{C}\right) .{ }^{24} \mathrm{In}$ a further development Ljungkvist's group ${ }^{25}$ trapped benzene on a solid adsorbent after passing through a membrane-based extraction unit. The analyte was thermally desorbed and subjected to GC-MS analysis. The lower limits of detection and determination were found to be $12 \mathrm{ng} / \mathrm{dm}^{3}$ and $35 \mathrm{ng} / \mathrm{dm}^{3}$ respectively, suggesting the application of this procedure for assessment of benzene exposure in occupationally exposed subjects. Alkalde et al. ${ }^{26}$ used HS-SPME coupled with GC-MS for rapid (<10 min) analysis of benzene in urine samples with a detection limit of $0.31 \mathrm{ppb}$ and the recovery of $99.3 \%$. Prado et al. ${ }^{27}$ evaluated the effects of various factors to optimize urinary benzene determination using SPME and GC-MS. The adequate conditions were found to be: extraction temperature $15^{\circ} \mathrm{C}$, incubation time $1 \mathrm{~min}$, extraction time $1 \mathrm{~min}$ and $2.5 \mathrm{~cm}^{3}$ sample volume. The lower limit of detection was 0.043 $\mathrm{ng} / \mathrm{cm}^{3}$. Another sensitive method (detection limit, 0.28$0.5 \mathrm{ppb}$ ) based on HS-SPME coupled with GC-MS was reported for simultaneous determination of benzene, toluene and xylene in $1 \mathrm{~cm}^{3}$ of urine sample. ${ }^{28}$ Whereas, Waidyanatha et al. ${ }^{29}$ used only $0.5 \mathrm{~cm}^{3}$ sample volume for the analysis of urinary benzene by HS-SPME and GC-MS. The high sensitivity (detection limit, 0.016 $\mu \mathrm{g} / \mathrm{dm}^{3}$ ) of this method was able to determine urinary benzene in control subjects with a mean level of 0.145 $\mu \mathrm{g} / \mathrm{dm}^{3}$ (range, $0.027-2.06 \mu \mathrm{g} / \mathrm{dm}^{3}$ ).

\section{Water}

Barnung and Grahl-Nielsen ${ }^{30}$ applied purge and trap technique for the concentration of benzene from water samples. The benzene was purged from the water by helium, trapped on an adsorbent (Tenax-GC), desorbed by rapid heating and transferred directly to a fused silica GC column. Using this procedure the benzene concentration of $0.1 \mu \mathrm{g} / \mathrm{dm}^{3}$ from $5 \mathrm{~cm}^{3}$ water samples can be determined. Rosell et al. ${ }^{31}$ optimized purge and trap GC-MS procedure for simultaneous determination of $\mathrm{ng} / \mathrm{dm}^{3}$ to sub $\mu \mathrm{g} / \mathrm{dm}^{3}$ levels of BTEX together with other organics in groundwater. Przyjazny and Kokosa ${ }^{32}$ described analyti- 
cal characteristics of HS-GC for determination of BTEX in water samples. Another rapid and reproducible method has been described for the determination of BTEX using solid-phase extraction followed by GC-FID. ${ }^{33}$ Hexane pretreated water samples were applied to $\mathrm{C}_{18}$ SPE column and BTEX were extracted with dichloromethane. These investigators reported $>90 \%$ recovery of BTEX from $200 \mathrm{~cm}^{3}$ of hexane-pretreated water samples using $\mathrm{C}_{18}$ adsorbent cartridges prior to GC-FID analysis. ${ }^{34} \mathrm{Re}-$ cently, Almeida and Boas ${ }^{35}$ determined BTEX in water samples using SPME and GC-FID. The detection limit for benzene was found to be $15 \mathrm{ng} / \mathrm{cm}^{3}$. Arambarri et $a l .{ }^{36}$ developed a simple and rapid HS-GC procedure for simultaneous determination of BTEX and alkyl ethers in water samples. The method was applied for the screening of contaminants in river water with the determination limit of benzene as $0.07 \mu \mathrm{g} / \mathrm{dm}^{3}$.

\section{Cigarette Smoke}

A simple, direct, and quantitative method using isotope dilution GC-MS was developed for the determination of benzene in mainstream vapor phase cigarette smoke. ${ }^{37}$ Vapor phase samples were collected cryogenically in a series of four traps following removal of the particulate phase with a Cambridge filter pad, recovering 75-85\% of the total amounts in the initial trap and less than $1 \%$ in the final trap. ${ }^{37}$ Brunnemann et al. ${ }^{38}$ trapped benzene from cigarette smoke in methanol using three midget impingers at $-78{ }^{\circ} \mathrm{C}$ prior to analysis by GC-MS. Darrall and coworkers ${ }^{39}$ determined BTEX and other volatile compounds including styrene, isoprene and acrylonitrile in mainstream smoke of 26 cigarette brands using GC-MS.

\section{Cookware}

HS-GC has also been used for the analysis of benzene in recycled polyethylene terephthalate (PETE) beverage bottles ${ }^{40}$ and in non-stick cookware. ${ }^{41}$ Jickells et al. ${ }^{42}$ used HS-GC to study migration of benzene originated from tert-butyl perbenzoate (which is often present in plastic cookware) to cooked food. Samples of thermoset polyester showed migration levels of 1.9 to $5.6 \mathrm{mg} / \mathrm{kg}$ in olive oil after extraction for 1 hour at $175^{\circ} \mathrm{C}$. Whereas migration levels into olive oil at the same temperature for samples produced with non-aromatic initiator were less than $0.1 \mathrm{mg} / \mathrm{kg}$. Varner et $\mathrm{al} .{ }^{43}$ analyzed benzene in polypropylene food-packaging materials and food-contact paraffin waxes. The polymer was dissolved in hexadecane at $150{ }^{\circ} \mathrm{C}$ whereas the wax was melted in an $80^{\circ} \mathrm{C}$ oven. A simple helium-sparging apparatus was used to remove the volatile chemical, collected in methanol and analyzed by HS-GC equipped with a $30 \mathrm{~m}$ fused silica open tubular capillary column and a photoionization detector. Average recoveries of benzene from polymer and paraffin wax were 63 and $70 \%$ with the quantitation limits of 17 and $2 \mathrm{ppb}$, respectively. ${ }^{43}$

\section{Soil}

A simultaneous detection of BTEX in soil has been performed using GC-FID. ${ }^{44}$ BTEX-dosed or contaminated soil $(20 \mathrm{~g})$ was mixed with anhydrous sodium sulfate and extracted with methylene chloride using Soxhlet apparatus. Two other methods of extraction based on shaking and sonication were also reported. The extract was concentrated and injected in GC where the detection limit for BTEX was found to be $0.8 \mathrm{mg} / \mathrm{dm}^{3}{ }^{34}$ Recently multiple-headspace (MHS)-SPME coupled with GC-FID has been applied for the determination of BTEX in soil samples. ${ }^{45}$ The sampling was performed for $30 \mathrm{~min}$ at $30{ }^{\circ} \mathrm{C}$ while the number of MHS-SPME ranged 2 (for dilute solutions) and 4 (for more concentrated solutions) to completely extract the analytes. The lower limit of detection for benzene was $0.2 \mathrm{ng}$ whereas the linear range was $0.44-158 \mathrm{ng}$.

Miscellaneous (adhesives, fruits, gasoline, oil, milk, tissue)

A purge-and-trap GC-MS procedure has been described for the determination of benzene in adhesive with recoveries of 70-85\% and detection limit of 10 ppm. ${ }^{46}$ Gorna-Binkul et al. ${ }^{47}$ isolated BTEX from fruits and vegetables using solvent extraction followed by their determination by GC-MS. Pavlova and Ivanova ${ }^{48}$ developed GC-FID method for determination of benzene in gasoline. Comparison of two capillary columns, PONA and TCEP revealed that GC-FID with TCEP column had several advantages including simplicity of handling, high precision and accurate measurement of benzene content. ${ }^{48}$ HS-GC coupled with MS detection was used for the analysis of BTEX in olive oil samples (Pena 2004). ${ }^{49}$ No special sample pretreatment was necessary except the use of $600 \mathrm{~mm}^{3}$ of ethyl acetate as a chemical modifier per $10 \mathrm{~cm}^{3}$ of oil sample. The detection limit of this procedure ranged 3-9 $\mathrm{ng} / \mathrm{cm}^{3}$. Estimation of benzene and toluene in human milk was performed using the techniques of purge-and-trap coupled with GC-MS. ${ }^{50}$ Bechtold et al..$^{51}$ performed the analysis of benzene in animal tissue by HPLC. Benzene was extracted with ethyl acetate and analyzed by reversed-phase HPLC using liquid scintillation spectrometry and UV absorption for detection.

\section{Analysis of Metabolites}

Khoschsorur and Petek ${ }^{52}$ reported a rapid and sensitive method for determination of benzene metabolites phenol and $p$-cresol in human urine samples. One microliter of urine was acid hydrolyzed, saturated with $\mathrm{NaCl}$ and then extracted with diethyl ether. The ether phase was evaporated to dryness, reconstituted with $\mathrm{CCl}_{4}$ and analyzed by GC-FID. The detection limit was $0.1 \mu \mathrm{g} / \mathrm{cm}^{3}$. Einig et $a l .53$ used GC electron capture detection for the measu- 
rement of urinary $S$-PMA after precolumn derivetization and HPLC cleanup. The detection limit of this sensitive method was found to be $60 \mathrm{ng} / \mathrm{dm}^{3}$. Waidyanatha et al. ${ }^{54}$ developed a GC-MS procedure for determination of urinary $t, t$-MA and $S$-PMA with detection limits of 10 $\mu \mathrm{g} / \mathrm{dm}^{3}$ and $2 \mu \mathrm{g} / \mathrm{dm}^{3}$, respectively. A capillary electrochromatography (EC) method for separation, detection and determination of $t, t$-MA in urine has been used. ${ }^{55}$ The sample was filtered through 0.22 micron membrane and injected in a capillary ( $75 \mu \mathrm{m}$ i.d. and $80 \mathrm{~cm}$ length). The analysis was conducted using the electrolyte consisted of $0.1 \mathrm{mmol} \mathrm{dm}^{-3}$ cetyltrimethyl ammonuim bromide in 60 mmol dm${ }^{-3}$ phosphate buffer $(\mathrm{pH}=7)$, constant voltage of $30 \mathrm{kV}$ and UV detection at $262 \mathrm{~nm}$. The sensitivity was $25 \mu \mathrm{g} / \mathrm{dm}^{3}$ and the percent recovery was $100 \pm 8 \%$.

The urinary $S$-PMA in mouse was analyzed by HPLC using ODS column, tetrabutylammonium hydrogen sulfate-methanol $(75: 25, v / v)$ as mobile phase and the absorbing wavelength at $255 \mathrm{~nm}$ for detection. ${ }^{56}$ The urine sample was first preconcentrated on anion exchange resin, extracted with diethyl ether and evaporated to dryness, then dissolved in aqueous phosphoric acid and injected into HPLC system. The detection limit of this method was found to be $3 \mathrm{mg} / \mathrm{dm}^{-3}$ in mouse urine. Lee et al. ${ }^{57}$ reported a sensitive HPLC method with fluorescence detection for simultaneous determination of hydroquinone, catechol and phenol in urine samples. After acid hydrolysis the urine samples were saturated with sodium sulfate on $\mathrm{C}_{18}$ column with gradient elution using two mobile phases, $10 \mathrm{mmol} \mathrm{dm}^{-3}$ sodium acetate containing $0.5 \%(v / v)$ acetic acid, with and without $20 \%(v / v)$ acetonitrile. In another method for quantitative measurement of $t, t-\mathrm{MA}$, catechol, hydroquinone and phenol in urine, the hydrolyzed mixture of benzene metabolites was purified and separated by solid-phase extraction with an anion exchanger followed by extraction with diethyl ether. ${ }^{58}$ The clean-up procedure reduced the natural background from mouse urine so that the detection limit of the metabolites was in the range of 3-60 mg/dm 3 . Buratti et al. ${ }^{59}$ used solid-phase ion exchange chromatography for sample clean-up and HPLC for the analysis of $t, t$-MA, using reversed-phase C18 column, UV detection at $263 \mathrm{~nm}$ and a mobile phase consisted of formic acid-tetrahydrofuran-water (14:17:969). The recovery of $t, t$-MA from urine samples was $>95 \%$ in $50-500 \mu \mathrm{g} / \mathrm{dm}^{3}$ range. Maestri and coworkers ${ }^{60}$ determined urinary $t, t$-MA by HPLC with $\mathrm{UV}$ detection at $259 \mathrm{~nm}$. The detection limit and recovery were $3 \mu \mathrm{g} / \mathrm{dm}^{3}$ and $90 \%$ respectively. Tharnpoophasiam et al. ${ }^{61}$ simultaneously analyzed urinary $t, t$-MA and $S$ PMA by liquid extraction with ethyl acetate followed by reversed-phase HPLC on Hypersil-ODS column using gradient mobile phase of methanol and perchloric acid and diode array detection at $205 \mathrm{~nm}$ (S-PMA) and 264 $\mathrm{nm}(t, t$-MA). The recoveries of both the metabolites were $>97 \%$. Marrubini et al. ${ }^{62}$ reported a coupled column liquid chromatography for the estimation of $t, t$-MA in human urine. The first column was packed with Microspher $\mathrm{C} 18$ and the second column with Hypersil-ODS. $t, t$-MA was detected by UV detection at $264 \mathrm{~nm}$ with the detection limit of $0.05 \mathrm{mg} / \mathrm{dm}^{3}$.

Melikian et al. ${ }^{63}$ developed a sensitive and specific liquid chromatography-tandem mass spectrometry (LC/ MS/MS) assay for quantitation of benzene metabolites $t, t$-MA, $S$-PMA, hydroquinone and catechol in urine specimens. The efficiency of this assay was evaluated in human urine specimens from smokers and nonsmokers serving as benzene-exposed and nonexposed groups respectively. Barbieri et al. ${ }^{64}$ also used LC/MS/MS for determination of $t, t$-MA and $S$-PMA in urine samples after SPME based purification. The limit of detection was found to be $6 \mu \mathrm{g} / \mathrm{dm}^{3}$ for $t, t-\mathrm{MA}$ and $0.3 \mu \mathrm{g} / \mathrm{dm}^{3}$ for $S$-PMA. Recently, a simple and rapid method using reversed-phase LC/MS/MS has been reported for simultaneous determination of urinary metabolites of benzene, toluene, xylene and styrene. ${ }^{65} t, t$-MA, hippuric acid, $o-$, $m$ - and $p$-methyl hippuric acid and phenylglyoxalic acid were separated on reversed-phase LC C-18 column (1 $\mathrm{mm}$ i.d.). Average recoveries of these metabolites from $100 \mathrm{~mm}^{3}$ urine sample were $88-110 \%$ and the quantification limits were less than $30 \mathrm{ng} / \mathrm{cm}^{3}$ for each analyte $\left(3 \mathrm{ng} / \mathrm{cm}^{3}\right.$ for $\left.t, t-\mathrm{MA}\right)$.

\section{CONCLUSION}

Chromatographic methods are efficiently used for the analysis of benzene and its metabolites in a wide variety of matrices. The limits of detection associated with these methods are quite diverse due to variations in the efficiency of extraction/preconcentration techniques, recovery from chromatography columns, and the sensitivity of the detectors used. Most of the recent studies applied SPME and HS-GC for the estimation of benzene. SPME presents extraordinary advantages over traditional extraction methods, because it integrates sampling, extraction, concentration and introduction of sample in a single stage, which significantly minimizes the use of solvents. ${ }^{66-68}$ Moreover, the requirement of small amount of sample for SPME renders the technique highly suitable for the analysis of benzene in biological fluids. ${ }^{66}$ On the other hand, headspace sampling provides the advantage of protecting fiber from any damages (interferences) caused by high molecular weight substances and other non-volatile contaminants present in sample matrix. ${ }^{68}$ Thus, the advents of SPME and HS have greatly reduced the complications associated with sample extraction and matrix effects. For chromatographic separations, GC appears to be a method of choice for the analysis of benzene, whereas HPLC is commonly applied for the estimation of benzene metabolites. 


\section{REFERENCES}

1. International Agency for Research on Cancer (IARC), IARC Monographs on the Evaluation of the Carcinogenic Risk of Chemicals to Humans, Suppl. 7, Lyon, 1987.

2. N. Rothman, W. E. Bechtold, S. N. Yin, M. Dosemeci, G. L. Li, Y. Z. Wang, W. C. Griffith, M. T. Smith, and R. B. Hayes, Occup. Environ. Med. 55 (1998) 705-711.

3. Q. Qu, A. A. Melikian, G. Li, R. Shore, L. Chen, B. Cohen, S. Yin, M. R. Kagan, H. Li, M. Meng, X. Jin, W. Winnik, Y. Li, R. Mu, and K. Li, Am. J. Ind. Med. 37 (2000) 522-531.

4. S. Ghittori, L. Maestri, M. L. Fiorentino, and M. Imbriani, Int. Arch. Occup. Environ. Health 67 (1995) 195-200.

5. G. M. Ljungkvist and R. G. Nordlinder, Am. Ind. Hyg. Assoc. J. 56 (1995) 693-697.

6. E. Yamada, Y. Hosokawa, Y. Furuya, K. Matsushita, and Y. Fuse, Anal. Sci. 20 (2004) 107-112.

7. E. Davoli, L. Cappellini, M. Moggi, S. Ferrari, and R. Fanelli, Int. Arch. Occup. Environ. Health 68 (1996) 262-267.

8. A. Saba, A. Cuzzola, A. Raffaelli, S. Pucci, and P. Salvadori, Rapid Commun. Mass Spectrom. 15 (2001) 2404-2408.

9. T. Amagai, T. Ohura, T. Sugiyama, M. Fusaya, and H. Matsushita, J. AOAC Int. 85 (2002) 203-211.

10. R. C. Wester, H. I. Maibach, L. D. Gruenke, and J. C. Craig, J. Toxicol. Environ. Health, 18 (1986) 567-573.

11. L. D. Gruenke, J. C. Craig, R. C. Wester, and H. I. Maibach, J. Anal. Toxicol. 10 (1986) 225-232.

12. K. Elke, E. Jermann, J. Begerow, and L. Dunemann, J. Chromatogr., A 826 (1998) 191-200.

13. S. Tumbiolo, J. F. Gal, P. C. Maria, and O. Zerbinati, Anal. Bioanal. Chem. 380 (2004) 824-830.

14. C. N. Ong and B. L. Lee, J. Chromatogr., B 660 (1994) 122.

15. K. Pekari, M. L. Riekkola, and A. Aitio, J. Chromatogr. 491 (1989) 309-320.

16. A. P. Alegretti, F. V. Thiesen, and G. P. Maciel, J. Chromatogr., B 809 (2004) 183-187.

17. P. W. Kok and C. N. Ong, Int. Arch. Occup. Environ. Health 66 (1994) 195-201.

18. X. P. Lee, T. Kumazawa, and K. Sato, Int. J. Legal Med. 107 (1995) 310-313.

19. L. Perbellini, F. Pasini, S. Romani, A. Princivalle, and F. Brugnone, J. Chromatogr., B 778 (2002) 199-210.

20. M. L. Fiorentino, S. Ghittori, and G. Pezzagno, Med. Lav. 81 (1990) 107-118.

21. G. Ljungkvist, M. Larstad, and L. Mathiasson, J. Chromatogr., B 721 (1999) 39-46.

22. S. Fustinoni, R. Giampiccolo, S. Pulvirenti, M. Buratti, and A. Colombi, J. Chromatogr., B 723 (1999) 105-115.

23. L. Skender, I. Brcic, and S. Zuzul, Arh. Hig. Rada. Toksikol. 53 (2002) 197-202.

24. G. Ljungkvist, M. Larstad, and L. Mathiasson, Analyst 126 (2001) 41-45.

25. G. Ljungkvist, A. Azimi, and L. Mathiasson, J. Environ. Monit. 6 (2004) 143-146.

26. T. K. Alkakde, M. C. R. Peralba, C. A. Zini and E. B. Caramao, J. Chromatogr., A 1027 (2004) 37-40.

27. C. Prado, J. Garrido, and J. F. Periago, J. Chromatogr., B 804 (2004) 255-261.

28. A. T. Kramer, R. P. M. de Carmo, Z. C. Alcaraz, and C. E. Bastos, J. Chromatogr. A. 1027 (2004) 37-40.
29. S. Waidyanatha, N. Rothman, S. Fustinoni, M. T. Smith, R. B. Hayes, W. Bechtold, M. Dosemeci, L. Guilan, S. Yin, and S. M. Rappaport, Carcinogenesis 22 (2001) 279-286.

30. T. N. Barnung and O. Grahl-Nielsen, J. Chromatogr. 466 (1989) 271-278.

31. M. Rosell, S. Lacorte, A. Ginebreda, and D. Barcelo, J. Chromatogr., A 995 (2003) 171-184.

32. A. Przyjazny and J. M. Kokosa, J. Chromatogr., A 977 (2002) 143-153.

33. M. A. Mottalab, M. Z. Abedin, and M. S. Islam, Anal. Sci. 19 (2003) 1365-1369.

34. M. A. Mottalab, M. Z. Abedin and M. S. Islam, J. Environ. Sci. 16 (2004) 497-501.

35. C. M. Almeida and L. V. Boas, J. Environ. Monit. 6 (2004) $80-88$.

36. I. Arambarri, M. Lasa, R. Garcia, and E. Millan, J. Chromatogr., A 1033 (2004) 193-203.

37. G. D. Byrd, K. W. Fowler, R. D. Hicks, M. E. Lovette, and M. F. Borgerding, J. Chromatogr. 503 (1990) 359-368.

38. K. D. Brunnemann, M. R. Kagan, J. E. Cox, and D. Hoffmann, Exp. Pathol. 37 (1989) 108-113.

39. K. G. Darrall, J. A. Figgins, R. D. Brown, and G. F. Phillips, Analyst 123 (1998) 1095-1101.

40. V. Komolprasert, W. A. Hargraves, and D. J. Armstrong, Food Addit. Contam. 11 (1994) 605-614.

41. S. M. Jickells, M. R. Philo, J. Gilbert, and L. Castle, J. AOAC Int. 76 (1993) 760-764.

42. S. M. Jickells, C. Crews, L. Castle, and J. Gilbert, Food Addit. Contam. 7 (1990) 197-205.

43. S. L. Varner, H. C. Hollifield, and D. Andrzejewski, J. AOAC Int. 74 (1991) 367-374.

44. H. S. Shin and O. S. Kwon, Bull. Korean Chem. Soc. 21 (2000) 1101-1105.

45. O. Ezquerro, G. Ortiz, B. Pons, and M. T. Tena, J. Chromatogr., A 1035 (2004) 17-22.

46. T. L. Barry, G. Petzinger, G. Lehr, and J. J. Specchio, J. AOAC Int. 78 (1995) 413-418.

47. A. Gorna-Binkul, R. Keymeulen, H. Van Langenhove, and B. Buszewski, J. Chromatogr., A 734 (1996) 297-302.

48. A. Pavlova and R. Ivanova, Acta. Chromatogr. 13 (2003) 215-225.

49. F. Pena, S. Cardenas, M. Gallego, and M. Valcarcel, J. Chromatogr., A 1052 (2004) 137-143.

50. F. Fabietti, A. Ambruzzi, M. Delise, and M. R. Sprechini, Environ. Int. 30 (2004) 397-401.

51. W. E. Bechtold, P. J. Sabourin and R. F. Henderson, J. Anal. Toxicol. 12 (1988) 176-179.

52. G. A. Khoschsorur and W. Petek, Anal. Sci. 16 (2000) 589591.

53. T. Einig, L. Dunemann, and W. Dehnen, J. Chromatogr., $B$ 687 (1996) 379-385.

54. S. Waidyanatha, N. Rothman, G. Li, M. T. Smith, S. Yin, and S. M. Rappaport, Anal. Biochem. 327 (2004) 184-199.

55. M. X. Coutrim, A. V. Jager, L. R. deCarvalho, and M. F. Tavares, J. Capillary Electrophor. Microchip. Technol. 4 (1997) $39-45$.

56. P. M. Schlosser, J. A. Bond, and M. A. Medinsky, Carcinogenesis 14 (1993) 2477-2486.

57. B. L. Lee, A. L. New, P. W. Kok, H. Y. Ong, C. Y. Shi, and C. N. Ong, Clin. Chem. 39 (1993) 1788-1792. 
58. H. Schad, F. Schafer, L. Weber, and H. J. Seidel, J. Chromatogr. 593 (1992) 147-151.

59. M. Buratti, S. Fustinoni, and A. Colombi, J. Chromatogr., B 677 (1996) 257-263.

60. L. Maestri, S. Ghittori, M. L. Fiorentino, and M. Imbriani, Med. Lav. 86 (1995) 40-49.

61. P. Tharnpoophasiam, P. Kongtip, W. Wongwit, W. Fungladda, and D. Kitayaporn, Southeast Asian J. Trop. Med. Pub. Health 35 (2004) 717-723.

62. G. Marrubini, T. Coccini, and L. Manzo, J. Chromatogr., B 758 (2001) 295-303.

63. A. A. Melikian, M. Meng, R. O'Connor, P. Hu, and S. M. Thompson, Res. Rep. Health Eff. Inst. 87 (1999) 1-36.
64. A. Barbieri, L. Sabatini, A. Accorsi, A. Roda, and F. S. Violante, Rapid Commun. Mass Spectrom. 18 (2004) 1983-1988.

65. S. Marchese, R. Curini, A. Gentili, D. Perret, and L. M. Rocca, Rapid Commun. Mass Spectrom. 18 (2004) 265-272.

66. S. Fustinoni, R. Giampiccolo, S. Pulvirenti, M. Burrati, and A. Colombi, J. Chromatogr., B 723 (1999) 105-115.

67. G. L. Hook, G. L. Kim, T. Hall, and P. A. Smith, Anal. Chem. 21 (2002) 534-543.

68. Z. Wang, K. Li, M. Fingas, L. Sigouin, and L. Menard, J. Chromatogr., A 971 (2002) 173-184.

\section{SAŽETAK}

\section{Kratki pregled kromatografskih metoda za analizu benzena i njegovih metabolita}

\section{Haseeb Ahmad Khan}

Benzen je značajno zagađivalo s mogućim kancerogenim djelovanjem. Glavni izvori izloženosti benzenu su njegova nesmanjena industrijska uporaba, benzinske pare, ispuštanje iz motora i duhanski dim. Izloženost benzenu u okolišu i na radnom mjestu predstavlja ozbiljnu opasnost za zdravlje. Stoga je ispitivanje benzena nužno za praćenje kakvoće okoliša. Metaboliti benzena, posebice $S$-fenilmerkapturna kiselina $(S$-PMA) i trans, trans-mukonska kiselina ( $t, t$-MA) rabe se kao osjetljivi biomarkeri izloženosti benzenu. Utvrđivanje nemetaboliziranoga benzena u urinu također predstavlja pouzdani pokazatelj izloženosti benzenu. U članku su opisane kromatografske metode za utvrđivanje benzena i njegovih metabolita u različitim okolišnim i biološkim uzorcima. 